\title{
Nutrient Supplementation Configures the Bioactive Profile and Production Characteristics of Three Brassica L. Microgreens Species Grown in Peat-Based Media
}

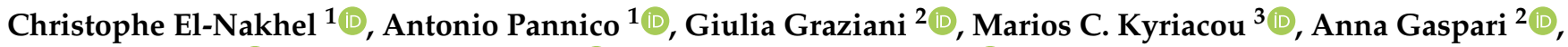 \\ Alberto Ritieni $^{2}\left(\mathbb{D}\right.$, Stefania De Pascale ${ }^{1}(\mathbb{D})$ and Youssef Rouphael ${ }^{1, *(1)}$ \\ 1 Department of Agricultural Sciences, University of Naples Federico II, 80055 Portici, Italy; \\ christophe.elnakhel@unina.it (C.E.-N.); antonio.pannico@unina.it (A.P.); depascal@unina.it (S.D.P.) \\ 2 Department of Pharmacy, University of Naples Federico II, 80131 Naples, Italy; \\ giulia.graziani@unina.it (G.G.); annagaspari@virgilio.it (A.G.); alberto.ritieni@unina.it (A.R.) \\ 3 Department of Vegetable Crops, Agricultural Research Institute, 1516 Nicosia, Cyprus; m.kyriacou@ari.gov.cy \\ * Correspondence: youssef.rouphael@unina.it
}

\section{check for} updates

Citation: El-Nakhel, C.; Pannico, A.; Graziani, G.; Kyriacou, M.C.; Gaspari,

A.; Ritieni, A.; De Pascale, S.;

Rouphael, Y. Nutrient

Supplementation Configures the Bioactive Profile and Production Characteristics of Three Brassica $L$. Microgreens Species Grown in Peat-Based Media. Agronomy 2021, 11, 346. https://doi.org/10.3390/ agronomy11020346

Academic Editor: Pilar Soengas

Received: 14 January 2021

Accepted: 12 February 2021

Published: 15 February 2021

Publisher's Note: MDPI stays neutral with regard to jurisdictional claims in published maps and institutional affiliations.

Copyright: (c) 2021 by the authors. Licensee MDPI, Basel, Switzerland. This article is an open access article distributed under the terms and conditions of the Creative Commons Attribution (CC BY) license (https:// creativecommons.org/licenses/by/ $4.0 /)$.
Abstract: Brassica L. microgreens are a fresh microscale vegetable crop of high antioxidant value and naturally dense in nutrients without the intervention of biofortification or genetic engineering. A climate chamber experiment on peat-based substrate was set up to test microgreens growth and accumulation of secondary metabolites in response to nutrient supplementation. Microgreens mineral content was analyzed through ion chromatography and total ascorbic acid through UVVis spectrophotometry, while carotenoids and phenolic acids were quantified by HPLC-DAD and UHPLC-HRMS, respectively. Brussels sprouts and cabbage yield was only reduced by $10 \%$, while nitrate was reduced by $99 \%$ in the absence of nutrient supplementation. Rocket yield was prominently reduced by $47 \%$, with a corresponding nitrate reduction of $118 \%$. Brussels sprouts secondary metabolites were not improved by the absence of nutrient supplementation, whereas cabbage microgreens demonstrated a $30 \%$ increase in total ascorbic acid and a $12 \%$ increase in total anthocyanins. As for rocket, the absence of nutrient supplementation elicited an extensive increase in secondary metabolites, such as lutein $(110 \%), \beta$-carotene (30\%), total ascorbic acid (58\%) and total anthocyanins $(20 \%)$, but caused a decrease in total phenolic acids. It is hereby demonstrated that growing microgreens on a commercial peat-based substrate without nutrient supplementation can be feasible for certain species. Moreover, it might elicit a species-dependent spike in bioactive secondary metabolites.

Keywords: Brassicaceae; bioactive compounds; nutritional stress; Brassica L. oleracea var. gemmifera; Brassica L. oleracea var. capitata; Diplotaxis tenuifolia

\section{Introduction}

Healthy diet narratives are trending among people seeking a propitious lifestyle; gastronomic pleasure interlaced with health-boosting foods is in great demand [1]. Countless phytochemicals impart benefits to human health [2,3] and substantiate the association of plant-rich diets with reduced disease incidence, especially among the elderly [2]. Indeed, the human organism's defense and immune system is affected by plant-based foods [4], which additionally partake in the pharmaceutical pipeline [5]. A copious number of characterized health-promoting phytochemicals are available in plant-derived products or in plants, per se [2], undeniably making vegetables an invaluable component of the human diet. Variegated plant pigmentation is valued for its biochemical diversity, which is attributed to substantial antioxidant activity [3]. A preponderant number of vegetables is rich in assorted biologically active secondary metabolites, including chlorophylls, carotenoids, phenolic compounds and others [6].

Brassica L. vegetables are widely planted and consumed all over the world [6-10], including Brussels sprouts, broccoli, cabbage, cauliflower, etc. [6,10], representing a mul- 
titude of edible organs such as roots, bulbs, heads and leaves and offering an enormous array of plant secondary metabolites [6]. Cartea et al. [8] stated that Brassica L. vegetables induce health enhancement through their complex blend of antioxidant phytochemicals. In particular, they are rich in fibers, vitamins $C$ and $E$, carotenoids, polyphenols, antioxidant enzymes and sulfur-organic compounds like glucosinolates $[3,6,9]$. These biochemical compounds conferred a major role to Brassica L. vegetables in clinical and epidemiological studies [6], since their inclusion in diets lowers the occurrence of carcinogenic mutations, averts oxidative stress and engenders detoxification enzymes [9].

Microgreens constitute a fresh popping crop with antioxidant punch, naturally dense in nutrients without the interference of biofortification or genetic engineering [11]. Their consumption is rising due to their high nutrient content $[1,12,13]$, vivid colors and intense flavors [14-16]; they are highly packed in secondary metabolites compared to their mature counterparts $[15,17,18]$. Notably, Brassica L. microgreens are a prominent choice due to their simple germination, short growing cycle and the potential health benefits attributed to their content of vitamins, polyphenols, glucosinolates, etc. $[3,13]$.

On the other hand, biochemical compositions are drastically managed by interacting genetic and environmental factors [5]. Deficient or unbalanced mineral nutrition is a form of abiotic stress that elicits an array of physiological cascades in plant secondary metabolism [5,19-21]. This makes nutrient deprivation a useful method to modulate the levels of functional compounds naturally [22,23], such as ascorbate, carotenoids and phenols; moreover, it may curtail anti-nutrient agents like nitrate [20]. Such intervention is effectively facilitated by soilless systems via accurate management of the nutrient solution concentration [20].

Few works have so far addressed microgreens response to nutrient solution concentration, such as Murphy and Phill [24], Wieth et al. [25] and Palmitessa et al. [26]. Our study intended to shed the light on novel species from the Brassicaceae botanical family and assess the changes precipitated in microgreens performance, including the levels of yield and bioactive components, in the absence of nutrients supplemented through irrigation. This approach can offer qualitative manipulation of the crop and curb production costs by limiting reliance on fertilizer supply. Herein, three Brassica L. microgreens species were cultivated on a peat-based substrate, with or without nutrient supplementation (control) in the form of quarter-strength Hoagland solution, in order to examine the potential effects in configuring the growth characteristics and bioactive secondary metabolites of select microgreens species.

\section{Materials and Methods}

\subsection{Climate Chamber Set Up, Genetic Material and Experimental Design}

A 16-day climate chamber experiment was carried out in the Department of Agricultural Sciences, University of Naples "Federico II", Portici, Italy. The climate chamber (KBP-6395F, Termaks, Bergen, Norway) was set at $24 / 18 \pm 2{ }^{\circ} \mathrm{C}$ day / night temperature, with a corresponding relative humidity of $70 / 80 \% \pm 5 \%$. The artificial light was delivered by a light-emitting diode panel (K 5 Series XL 750, Kind LED, CA, USA), consisting of an optimal absorption spectrum for photosynthesis, where wave lengths ranged between 400 and $700 \mathrm{~nm}$, at an intensity of $300 \pm 15 \mu \mathrm{mol} \mathrm{m}^{-2} \mathrm{~s}^{-1}$ at canopy level, set at a photoperiod of $12-12 \mathrm{~h}$.

Three Brassica L. genotypes were chosen for this experiment: Diplotaxis tenuifolia (Wild Rocket Napoli), CN Seeds Ltd., Pymoor, Ely, Cambrigeshire, UK; Brassica L. oleracea var. capitata (Green Cabbage Copenhagen); and Brassica oleracea var. gemmifera (Green Brussels sprouts Mezzo Nano), Pagano costantino \& F.lli S.R.L, Scafati (SA), Italy. The adopted sowing density was 16 seeds $\mathrm{cm}^{-2}$ for rocket and 6 seeds $\mathrm{cm}^{-2}$ for cabbage and Brussels sprouts. The germination of microgreens seeds occurred in darkness at $24{ }^{\circ} \mathrm{C}$ and $100 \%$ relative humidity. These microgreens were grown in $204 \mathrm{~cm}^{2}$ plastic trays filled with $600 \mathrm{~mL}$ peat moss mix each (pH 5.48 and EC $282 \mu \mathrm{S} \mathrm{cm}^{-1}$; Special Mixture, Floragard Vertriebs$\mathrm{GmbH}$, Oldenburg, Germany) and fertigated daily with a quarter-strength customized 
Hoagland nutrient solution ( $\mathrm{pH} 6.0 \pm 0.2$ and EC $400 \pm 50 \mu \mathrm{Sm}^{-1}$ ) or simply irrigated daily with distilled water ( $\mathrm{pH} 6.0 \pm 0.2$ and $\mathrm{EC} 3 \mu \mathrm{S} \mathrm{cm}^{-1}$ ). Both the nutrient solution and the substrate composition and concentration are listed in detail in Kyriacou et al. [27].

The trays were distributed based on a randomized design, with six factorial treatments $(2 \times 3)$ consisting of two fertigation solutions (no fertilizer or daily solution fertilization) and three microgreens genotypes (Brussel sprouts, cabbage or rocket); each treatment was replicated three times.

\subsection{Colorimetric Measurements, Harvest and Sampling}

Just before harvest, the CIELAB color space parameters were measured on the surface of the microgreens canopy through a Minolta CR-400 Chroma Meter (Minolta Camera Co. Ltd., Osaka, Japan) characterized by an $8 \mathrm{~mm}$ opening. All microgreens genotypes were harvested on the same day (16 days after sowing), when two true leaves were fully formed, by applying a cut just above substrate level. The harvested microgreens material was weighed immediately and expressed in $\mathrm{kg}$ fresh weight $(\mathrm{fw}) \mathrm{m}^{-2}$; one part was stored at $-80{ }^{\circ} \mathrm{C}$ for qualitative analysis and lyophilization purposes, and another part was placed in a forced-air oven in order to deduce the dry weight $(\mathrm{dw})$ and to calculate the dry matter percentage (DM). Both lyophilized and dried microgreens materials were ground (841 microns screen) for chemical and qualitative analysis.

\subsection{Mineral Content, Nitrate and Total Ascorbic Acid Assessment}

Oven-dried microgreens material was used in order to assess mineral and nitrate content following the method mentioned by Kyriacou et al. [12]. Briefly, $250 \mathrm{mg}$ of dried leaves and stems of microgreens were extracted in $50 \mathrm{~mL}$ Milli-Q water and shaken in a water bath (ShakeTemp SW 22, Julabo, Seelbach, Germany) for 10 min at $80^{\circ} \mathrm{C}$. After centrifugation, the supernatant was analyzed through ion chromatography (ICS- 3000, Dionex, California, USA) coupled to an electrical conductivity detector. Nitrate $\left(\mathrm{NO}_{3}\right)$, phosphorus $(\mathrm{P})$, potassium $(\mathrm{K})$, calcium $(\mathrm{Ca})$, magnesium $(\mathrm{Mg})$, sulfur $(\mathrm{S})$ and sodium $(\mathrm{Na})$ were quantified in $\mathrm{g} \mathrm{kg}^{-1} \mathrm{dw}$. On the basis of each sample's original $\mathrm{dw}$, nitrate values were converted consecutively to $\mathrm{mg} \mathrm{kg}^{-1} \mathrm{fw}$

For total ascorbic acid (TAA) analysis, $400 \mathrm{mg}$ of frozen fresh material was extracted and assessed at $525 \mathrm{~nm}$ through an UV-Vis spectrophotometer (Hach DR 4000; Hach Co, Loveland, CO, USA), following the method of Kampfenkel et al. [28]. The results were expressed as mg AA $100 \mathrm{~g}^{-1} \mathrm{fw}$.

\subsection{Chlorophyll Pigments, Carotenoid Extraction and Quantification by HPLC-DAD}

Lichtenhaler and Wellburn's [29] protocol was implemented in order to determine total chlorophyll content and chlorophylls a and b. For this determination, $500 \mathrm{mg}$ of frozen fresh material was extracted in $10 \mathrm{~mL}$ of $90 \%$ acetone and centrifuged, and then the absorbance of the supernatant was measured at 662 and $645 \mathrm{~nm}$ through spectrophotometry (Hach DR 4000; Hach Co., Loveland, CO, USA) to determine chlorophylls a and b, respectively. Total chlorophyll content was calculated as the sum of the two and expressed in $\mathrm{mg} 100 \mathrm{~g}^{-1} \mathrm{fw}$.

Following the modified method of Kim et al. [30] by Kyriacou et al. [12], $100 \mathrm{mg}$ of lyophilized microgreens material was extracted in $6 \mathrm{~mL}$ ethanol comprising $0.1 \%$ butylated hydroxytoluene. Lutein and $\beta$-carotene were quantified following a reverse Phase-HPLC separation through a Shimadzu HPLC LC 10 (Shimadzu, Osaka, Japan) and expressed in $\mathrm{mg} \mathrm{kg}^{-1} \mathrm{dw}$.

\subsection{Anthocyanin and Polyphenol Extraction}

Freeze-dried and powdered microgreens samples were extracted using the procedure reported by Huang et al. [31], with a few modifications. In particular, $100 \mathrm{mg}$ of sample were extracted with $2.5 \mathrm{~mL}$ of methanol/water $(70: 30, v / v)$ acidified with formic acid $(0.5 \%)$. The mixture was sonicated for $30 \mathrm{~min}$ at room temperature. The extracts were then centrifuged at $4000 \mathrm{rpm}$ for $10 \mathrm{~min}$ at $4{ }^{\circ} \mathrm{C}$, and the supernatant was filtered through a 
$0.2 \mu \mathrm{m}$ nylon membrane syringe filter (Phenomenex, Castel Maggiore, BO, Italy). Five microliters of the filtered extract were used for UHPLC-HRMS analysis.

\subsection{UHPLC-HRMS Analysis}

Chromatographic analysis was performed using an UHPLC system (Thermo Fisher Scientific, Waltham, MA, USA) equipped with a degassing system, a quaternary UHPLC pump and an autosampler device (Dionex Ultimate 3000). Anthocyanin and polyphenol separation was carried out on a thermostated $\left(25^{\circ} \mathrm{C}\right)$ Luna Omega PS $1.6 \mu \mathrm{m}(50 \mathrm{~mm} \times 2.1 \mathrm{~mm}$, Phenomenex) column. The injection volume was $5 \mu \mathrm{L}$. The mobile phases were Phase A (water with $0.1 \%$ formic acid $v / v$ ) and Phase B (acetonitrile with $0.1 \%$ formic acid $v / v$ ).

On a daily basis, a reference standard mixture provided by the manufacturer was used to check the accuracy and to calibrate the Q Exactive Orbitrap LC-MS/MS. In full scan MS and AIF modes, a 5 ppm mass tolerance window was set. An Xcalibur software v. 3.0.63 (Xcalibur, Thermo Fisher Scientific, Waltham, MA, USA) was implemented to perform data analysis and processing. All values were expressed in $\mu \mathrm{g} \mathrm{g}^{-1} \mathrm{dw}$.

\subsection{Statistics}

The experiment was performed in three replicates, and all data were shown as mean \pm standard error. The mean effect of the nutrient solution treatment $(\mathrm{T})$ was compared by $\mathrm{t}$-Test, while the interaction between the two factors, microgreens species $(\mathrm{M})$ and nutrient solution treatment $(\mathrm{T})$, was subjected to the analysis of variance (2-way ANOVA). Microgreens species $(M)$ mean effect and $M \times T$ interaction were assessed by Duncan's multiple range test (DMRT), performed at $p \leq 0.05$ (SPSS 20 software package).

\section{Results and Discussion}

\subsection{Microgreens Fresh Yield and Dry Matter Concentration}

The nutrient solution treatments applied to the three different microgreens genotypes revealed a significant interaction regarding yield (Figure 1A), which was prevalently marked in rocket. Replacement of the quarter-strength Hoagland nutrient solution (NS) with distilled water (C) elicited a pronounced decrease of $47.4 \%$ in rocket yield, compared to merely 12.0 and $7.9 \%$ for Brussels sprouts and cabbage microgreens, respectively. Similarly, dry matter content (DM) (Figure 1B) was affected by the $\mathrm{M} \times \mathrm{T}$ interaction between the two experimental factors comprising microgreens species $(\mathrm{M})$ and fertigation treatment $(\mathrm{T})$. Cabbage DM did not exhibit any significant difference between the two treatments, despite the slight decrease observed in fresh yield, whereas the DM of both Brussels sprouts and rocket increased in the control treatment by 9.8 and $26.8 \%$, respectively.

Both treatments had no effect on the growth cycle length of the three species, having reached the two-true leaves stage contemporarily 16 days after sowing. A similar growth cycle was obtained by Wieth et al. [25] for purple cabbage microgreens when grown on a similar substrate with comparable nutrient solutions. The same authors also demonstrated a significant decrease in cabbage fresh weight irrigated without fertilizers. As for the trend observed for rocket, it is in line with the one observed for arugula microgreens grown in peat-lite medium and harvested at DAT 15 in the work of Murphy and Phill [24], where shoot fresh weight decreased by $40 \%$ when the daily fertilization solution contained $0 \mathrm{mg} / \mathrm{L}$ of nitrogen compared to the other treatments containing $\mathrm{N}-\mathrm{P}_{2} \mathrm{O}_{5}-\mathrm{K}_{2} \mathrm{O}$, thus indicating the sensitivity of this species to fertilization effect, which was not the case for Brussels sprouts and cabbage that on average demonstrated only $10 \%$ of fresh weight reduction. A deficiency of administrated nutrients ( $\mathrm{N}$ and $\mathrm{P}$ ) reduces plant growth, development and leaf biomass [32]. Nonetheless, as mentioned by Toscano et al. [33], defensive flavonoids (e.g., anthocyanin) are expensive for plants, and their buildup induces a decrease in plant growth. This was clearly the case for rocket, which accumulated the most anthocyanins when treated with distilled water. On the other hand, the obtained DM was similar to what was obtained by Xiao et al. [14], who assessed 30 Brassica L. species, with arugula, Brussels sprouts and green cabbage registering $6.4,6.5$ and $6.1 \%$ DM, respectively. 


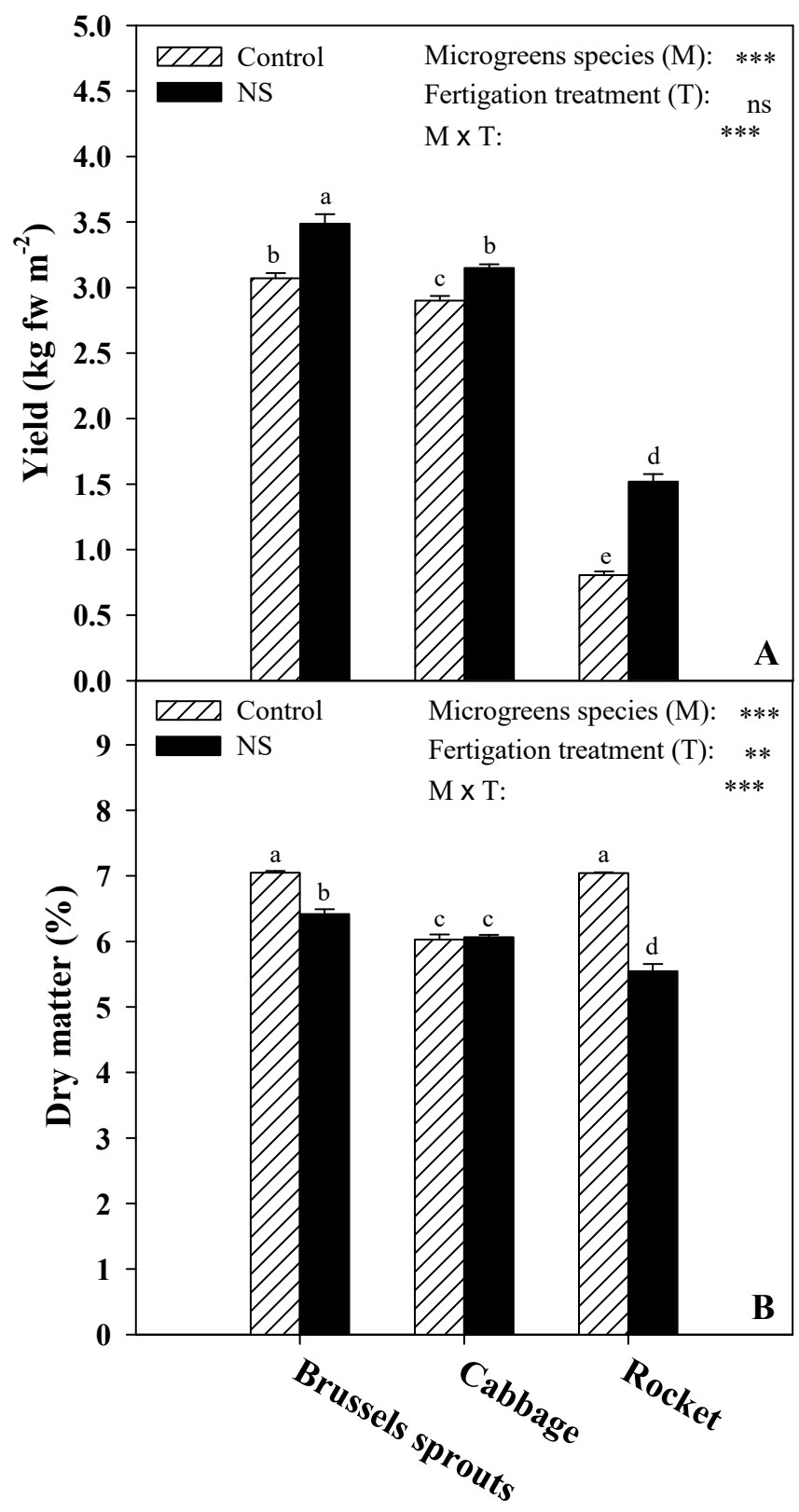

Figure 1. Yield (A) and dry matter (B) of Brussels sprouts, cabbage and rocket microgreens with respect to nutrient solution treatment. Control: without nutrient supplementation; NS: with nutrient supplementation. All data are expressed as mean $\pm \mathrm{SE}, \mathrm{n}=3$. $\mathrm{ns},{ }^{* *},{ }^{* * *}$ denote non-significant or significant effects at $p \leq 0.01$ and 0.001. Different letters (a-e; A and a-d; B) indicate significant differences compared by Duncan's multiple-range test $(p=0.05)$.

\subsection{Microgreens Leaf Colorimetric Parameters}

As listed in Table 1 , microgreens brightness $\left(\mathrm{L}^{*}\right)$ and hue angle $\left(\mathrm{h}^{\circ}\right)$ were not influenced by the fertigation treatment but were dictated by the genetic material. Brussels sprouts and cabbage had similar $L^{*}$ and $h^{\circ}$ values, which were significantly higher than those of rocket. On the other hand, a significant interaction of $\mathrm{M} \times \mathrm{T}$ was registered for chroma $\left(\mathrm{C}^{*}\right)$; Brussels sprouts and cabbage manifested no significant changes, whereas rocket registered a decrease around $17.7 \%$ in $C^{*}$ when fertigation was shifted to distilled water (i.e., without nutrient supplementation). 
Table 1. Microgreens canopy CIELAB color space parameters $\left(\mathrm{L}^{*}\right)$, chroma and hue angle in light of the nutrient solution treatment.

\begin{tabular}{|c|c|c|c|}
\hline Source of Variance & $\mathbf{L}^{*}$ & Chroma $\left(C^{*}\right)$ & Hue Angle (h) \\
\hline \multicolumn{4}{|l|}{ Microgreens species (M) } \\
\hline Brussels sprouts & $38.54 \pm 1.15 \mathrm{a}$ & $18.64 \pm 0.34 b$ & $113.8 \pm 0.30 \mathrm{a}$ \\
\hline Cabbage & $40.59 \pm 0.36 \mathrm{a}$ & $17.97 \pm 0.18 \mathrm{~b}$ & $114.0 \pm 0.31 \mathrm{a}$ \\
\hline Rocket & $\underset{* * * *}{32.78 \pm 1.48 b}$ & $22.30 \underset{* * *}{ \pm} 1.23 \mathrm{a}$ & $109.4 \underset{* * *}{ \pm 0.33 \mathrm{~b}}$ \\
\hline \multicolumn{4}{|l|}{ Fertigation treatment $(\mathrm{T})$} \\
\hline Control (C) & $36.22 \pm 1.66$ & $18.96 \pm 0.50$ & $112.3 \pm 0.78$ \\
\hline NS & $38.38 \pm 1.10$ & $20.32 \pm 1.11$ & $112.6 \pm 0.80$ \\
\hline$t$-test & ns & ns & ns \\
\hline \multicolumn{4}{|l|}{$\mathrm{M} \times \mathrm{T}$} \\
\hline Brussels sprouts $\times \mathrm{C}$ & $37.80 \pm 1.16$ & $18.86 \pm 0.52 b$ & $113.7 \pm 0.63$ \\
\hline Brussels sprouts $\times$ NS & $39.27 \pm 2.17$ & $18.41 \pm 0.50 \mathrm{~b}$ & $114.0 \pm 0.16$ \\
\hline Cabbage $\times \mathrm{C}$ & $40.67 \pm 0.29$ & $17.87 \pm 0.17 b$ & $113.7 \pm 0.46$ \\
\hline Cabbage $\times$ NS & $40.52 \pm 0.76$ & $18.08 \pm 0.35 b$ & $114.3 \pm 0.42$ \\
\hline Rocket $\times$ C & $30.19 \pm 1.50$ & $20.13 \pm 1.21 b$ & $109.3 \pm 0.68$ \\
\hline Rocket $\times$ NS & $\begin{array}{c}35.37 \pm 1.42 \\
\mathrm{~ns}\end{array}$ & $\begin{array}{c}24.46 \pm \\
*\end{array}$ & $\begin{array}{c}109.4 \pm 0.28 \\
\mathrm{~ns}\end{array}$ \\
\hline
\end{tabular}

Rocket chroma $\left(C^{*}\right)$ values under nutrient deprivation were in accordance with the findings of Islam et al. [34], where color intensity (chroma) was higher in the presence of a concentrated nutrient solution. Color measurements are indirect measurements of quality attributes like flavor and pigment content, since they correlate perfectly with physicochemical properties, as stated by Pathare et al. [35]. Leafy vegetable color is appealing to consumers in the quest of functional commodities [34], with chlorophylls imparting green, carotenoids yellow, orange and red, anthocyanins red and blue, flavonoids yellow and betalains red color [35].

\subsection{Microgreens Nitrate and Macro-Minerals Content}

Microgreens nitrate variation according to fertigation treatment is presented in Table 2. A significant $\mathrm{M} \times \mathrm{T}$ interaction was noted, as nitrate in Brussels sprouts and rocket was reduced by 107 -fold on average when irrigated with distilled water, while cabbage nitrate content decreased by 227 -fold, reaching $1.75 \mathrm{mg} \mathrm{kg}^{-1} \mathrm{fw}$. It is of note that, for all species, nitrate content was well under the limits imposed by European Commission Regulation (EU) No. 1258/2011, even when irrigated with nutrient supplementation, although rocket is characterized as a nitrate-accumulating species [36]. Actually, $80 \%$ of human exposure to nitrate derives from raw vegetable consumption [37]. In fact, nitrate accumulation in raw leafy vegetables is modulated by pre-harvest factors such as nitrogen concentration in the nutrient solution and the application timing, as mentioned by Kyriacou et al. [38]. The same authors emphasized that cutting of nitrate in the solution several days before harvesting in soilless agriculture is an optimum strategy to diminish nitrate in leafy vegetables. As a matter of fact, nitrate concentration obtained in nutrient-free solution treatment resulted in very low values, not exceeding an average of $3.41 \mathrm{mg} \mathrm{kg}^{-1} \mathrm{fw}$.

Regarding the analyzed macro-minerals (Table 2), calcium was the only mineral controlled by microgreens species, registering the highest value in cabbage, followed by Brussels sprouts and then rocket. All the other minerals were subject to $\mathrm{M} \times \mathrm{T}$ interaction. Brussels sprouts showed a $22.2 \%$ decrease in potassium content when irrigated with distilled water, while all other minerals maintained steady values between the treatments. A similar trend was noted for cabbage, where only the magnesium content was modified between treatments, incurring a $24.2 \%$ increase when irrigated without nutrient supplementation. For rocket microgreens, all the macro-minerals increased significantly in 
the control treatment, except for sulfur, which decreased nominally but not significantly compared to the nutrient supplementation treatment.

Several biological processes related to the growth and development of plants are based on the presence of minerals (17 key minerals), which are also conveyed to human nutrition [18]. The present results on microgreens macronutrient content were in the range obtained by Weber [11] on cabbage, by Kamal et al. [13] on Brussels sprouts and green cabbage and by Kyriacou et al. [12,27], who assessed several Brassica L. microgreens on peat-based substrate. Moreover, potassium and calcium were among the most abundant minerals detected in microgreens, which is in line with the results of Waterland et al. [39] for Brassica L. microgreens.

Table 2. Nitrate $\left(\mathrm{mg} \mathrm{kg}^{-1} \mathrm{fw}\right)$ and mineral $\left(\mathrm{mg} \mathrm{g}^{-1} \mathrm{dw}\right)$ content of Brussels sprouts, cabbage and rocket microgreens in light of the nutrient solution treatment.

\begin{tabular}{|c|c|c|c|c|c|c|c|}
\hline Source of Variance & Nitrate & $\mathbf{P}$ & $\mathbf{K}$ & $\mathrm{Ca}$ & Mg & $S$ & $\mathrm{Na}$ \\
\hline \multicolumn{8}{|l|}{ Microgreens species (M) } \\
\hline Brussels sprouts & $194.3 \pm 85.2 \mathrm{~b}$ & $4.33 \pm 0.12 \mathrm{a}$ & $14.08 \pm 0.86 \mathrm{~b}$ & $15.93 \pm 0.60 \mathrm{~b}$ & $5.47 \pm 0.10 \mathrm{a}$ & $2.60 \pm 0.19 b$ & $2.83 \pm 0.08 \mathrm{~b}$ \\
\hline Cabbage & $199.3 \pm 88.5 b$ & $3.05 \pm 0.12 b$ & $12.47 \pm 0.37 b$ & $18.97 \pm 0.68 \mathrm{a}$ & $5.47 \pm 0.29 \mathrm{a}$ & $4.35 \pm 0.17 \mathrm{a}$ & $3.98 \pm 0.15 \mathrm{a}$ \\
\hline Rocket & $270.4 \underset{* * *}{ \pm} 119 \mathrm{a}$ & $4.54 \underset{* * *}{ \pm 0.28 \mathrm{a}}$ & $37.00 \pm \underset{* * *}{ } 1.58 \mathrm{a}$ & $13.62 \pm \underset{* * *}{0.47 c}$ & $3.79 \underset{* * *}{ \pm 0.21 b}$ & $2.15 \pm \underset{* * *}{ \pm 0.19 b}$ & $3.80 \pm \underset{* * *}{0.42 \mathrm{a}}$ \\
\hline \multicolumn{8}{|l|}{ Fertigation treatment $(\mathrm{T})$} \\
\hline Control (C) & $3.41 \pm 0.51$ & $4.21 \pm 0.27$ & $21.76 \pm 4.63$ & $17.26 \pm 0.87$ & $5.27 \pm 0.27$ & $2.90 \pm 0.43$ & $3.82 \pm 0.33$ \\
\hline NS & $439.2 \pm 24.8$ & $3.73 \pm 0.25$ & $20.60 \pm 3.35$ & $15.08 \pm 0.77$ & $4.55 \pm 0.33$ & $3.17 \pm 0.28$ & $3.25 \pm 0.13$ \\
\hline$t$-test & $* * *$ & ns & ns & ns & ns & ns & ns \\
\hline \multicolumn{8}{|l|}{$\mathrm{M} \times \mathrm{T}$} \\
\hline Brussels sprouts $\times \mathrm{C}$ & $3.94 \pm 0.59 c$ & $4.27 \pm 0.13 b$ & $12.33 \pm 0.53 \mathrm{~d}$ & $17.05 \pm 0.16$ & $5.50 \pm 0.02 b$ & $2.31 \pm 0.10 \mathrm{bc}$ & $2.66 \pm 0.03 c$ \\
\hline Brussels sprouts $\times$ NS & $384.6 \pm 6.94 b$ & $4.39 \pm 0.23 b$ & $15.84 \pm 0.55 \mathrm{c}$ & $14.80 \pm 0.73$ & $5.45 \pm 0.22 \mathrm{~b}$ & $2.88 \pm 0.30 \mathrm{~b}$ & $3.01 \pm 0.02 c$ \\
\hline Cabbage $\times \mathrm{C}$ & $1.75 \pm 0.71 \mathrm{c}$ & $3.28 \pm 0.09 c$ & $12.70 \pm 0.75 \mathrm{~d}$ & $20.26 \pm 0.47$ & $6.06 \pm 0.03 \mathrm{a}$ & $4.57 \pm 0.22 \mathrm{a}$ & $4.19 \pm 0.23 \mathrm{ab}$ \\
\hline Cabbage $\times$ NS & $396.9 \pm 10.3 b$ & $2.82 \pm 0.10 c$ & $12.24 \pm 0.29 \mathrm{~d}$ & $17.68 \pm 0.67$ & $4.88 \pm 0.24 c$ & $4.14 \pm 0.21 \mathrm{a}$ & $3.76 \pm 0.09 \mathrm{~b}$ \\
\hline Rocket $\times \mathrm{C}$ & $4.54 \pm 0.26 c$ & $5.10 \pm 0.20 \mathrm{a}$ & $40.26 \pm 0.23 \mathrm{a}$ & $14.47 \pm 0.58$ & $4.25 \pm 0.12 \mathrm{~d}$ & $1.82 \pm 0.11 c$ & $4.60 \pm 0.49 a$ \\
\hline Rocket $\times$ NS & $536.2 \pm \underset{* * *}{ \pm} 11.6 \mathrm{a}$ & $\begin{array}{c}3.98 \pm 0.22 b \\
*\end{array}$ & $33.73 \underset{* * *}{ \pm} 1.33 \mathrm{~b}$ & $\begin{array}{c}12.77 \pm 0.24 \\
\mathrm{~ns}\end{array}$ & $\underset{* *}{3.33 \pm 0} 0.04 \mathrm{e}$ & $2.49 \pm \underset{*}{0.24 b c}$ & $2.99 \pm \underset{* *}{0.04 c}$ \\
\hline
\end{tabular}

$\mathrm{ns},{ }^{*}, * * * * *$ denote non-significant or significant effects at $p \leq 0.05,0.01$ and 0.001 . Control: without nutrient supplementation; NS: with nutrient supplementation. All data are expressed as mean $\pm \mathrm{SE}, \mathrm{n}=3$. Different letters within each column(s) indicate significant differences compared by Duncan's multiple-range test $(p=0.05)$.

\subsection{Microgreens Chlorophylls and Carotenoids Pigments}

Chlorophyll a concentration was dictated mainly by fertigation treatment (Table 3), with a 10.3\% decrease observed when the control treatment was applied. Chlorophyll b and total chlorophyll were dictated by the interaction of $\mathrm{M} \times \mathrm{T}$. Chlorophyll $\mathrm{b}$ decreased significantly in Brussels sprouts when irrigated without nutrient supplementation, while the same treatment decreased total chlorophyll in all microgreen species, although not significantly in rocket.

The decrease in total chlorophyll is partially in line with the findings of Wieth et al. [25], who saw diverse trends based on the growing substrate used; however, fully in line with other works where chlorophyll content (SPAD), which decreased with P deprivation [34]. In fact, $\mathrm{P}$ absence renders the energy lower and curbs photosynthesis [34]. Furthermore, leaf nitrogen is incorporated in chlorophyll, which reflects indirectly the nitrogen status [40]. Moreover, as stated by Berges et al. [41], nitrogen deprivation influences photochemical energy conversion due to a decrease in protein synthesis, which affects chloroplastic proteins related to photosystem I and II more than cytoplasmic proteins; this deprivation reduces the energy collection efficiency because of chlorophyll a loss.

As for the carotenoids listed in Figure 2, both lutein and $\beta$-carotene showed an interaction between the two factors, $\mathrm{M}$ and T. While both molecules decreased when Brussels sprouts and cabbage were irrigated without nutrient supplementation, they paradoxically increased in rocket. In fact, lutein registered $613.2 \mathrm{mg} \mathrm{kg}^{-1} \mathrm{dw}(110.9 \%$ increase) and $\beta$-carotene was $420.5 \mathrm{mg} \mathrm{kg}^{-1} \mathrm{dw}$ (30.4\% increase) when irrigated with distilled water. Whereas, lutein and $\beta$-carotene decreased by 14.3 and $16.4 \%$, respectively, in Brussels sprouts and cabbage on average. 
Table 3. Chlorophyll pigment, total ascorbic acid and total anthocyanins of Brussels sprouts, cabbage and rocket microgreens in light of the nutrient solution treatment.

\begin{tabular}{|c|c|c|c|c|c|}
\hline Source of Variance & $\begin{array}{l}\text { Chlorophyll a } \\
\left(\mathrm{mg} 100 \mathrm{~g}^{-1} \mathrm{fw}\right)\end{array}$ & $\begin{array}{l}\text { Chlorophyll b } \\
\left(\mathrm{mg} 100 \mathrm{~g}^{-1} \mathrm{fw}\right)\end{array}$ & $\begin{array}{l}\text { Total Chlorophylls } \\
\left(\mathrm{mg} 100 \mathrm{~g}^{-1} \mathrm{fw}\right)\end{array}$ & $\begin{array}{l}\text { Total Ascorbic Acid } \\
\left(\mathrm{mg} \text { AA } 100 \mathrm{~g}^{-1} \mathrm{fw}\right)\end{array}$ & $\begin{array}{c}\sum \text { Anthocyanin } \\
\left(\mu g^{-1} g^{-1}\right)\end{array}$ \\
\hline \multicolumn{6}{|l|}{ Microgreens species (M) } \\
\hline Brussels sprouts & $0.61 \pm 0.02 \mathrm{a}$ & $0.23 \pm 0.01 \mathrm{a}$ & $0.84 \pm 0.03 \mathrm{a}$ & $308.7 \pm 15.9 \mathrm{a}$ & $36.25 \pm 0.74 b$ \\
\hline Cabbage & $0.50 \pm 0.01 \mathrm{c}$ & $0.22 \pm 0.01 \mathrm{ab}$ & $0.72 \pm 0.02 \mathrm{~b}$ & $253.0 \pm 15.2 b$ & $52.45 \pm 1.51 \mathrm{a}$ \\
\hline Rocket & $0.55 \underset{* * *}{ \pm 0.01 b}$ & $\underset{*}{0.21 \pm 0.01 \mathrm{~b}}$ & $\underset{* * *}{0.75} \underset{* 01}{0.01 b}$ & $318.5 \underset{* * *}{ \pm} 32.5 \mathrm{a}$ & $29.10 \underset{* * *}{ \pm} 1.23 \mathrm{c}$ \\
\hline \multicolumn{6}{|l|}{ Fertigation treatment $(\mathrm{T})$} \\
\hline Control & $0.52 \pm 0.01$ & $0.21 \pm 0.00$ & $0.73 \pm 0.01$ & $318.0 \pm 18.4$ & $40.97 \pm 3.70$ \\
\hline NS & $0.58 \pm 0.02$ & $0.22 \pm 0.01$ & $0.81 \pm 0.03$ & $268.8 \pm 19.0$ & $37.57 \pm 3.35$ \\
\hline$t$-test & * & ns & $*$ & ns & ns \\
\hline \multicolumn{6}{|l|}{$\mathrm{M} \times \mathrm{T}$} \\
\hline Brussels sprouts $\times C$ & $0.56 \pm 0.02$ & $0.21 \pm 0.00 \mathrm{bc}$ & $0.77 \pm 0.02 \mathrm{~b}$ & $276.7 \pm 4.19 c$ & $35.75 \pm 1.27 c$ \\
\hline Brussels sprouts $\times$ NS & $0.66 \pm 0.01$ & $0.25 \pm 0.01 \mathrm{a}$ & $0.91 \pm 0.01 \mathrm{a}$ & $340.7 \pm 14.9 b$ & $36.75 \pm 0.92 c$ \\
\hline Cabbage $\times \mathrm{C}$ & $0.48 \pm 0.02$ & $0.21 \pm 0.01 \mathrm{bc}$ & $0.69 \pm 0.03 c$ & $286.5 \pm 3.92 \mathrm{c}$ & $55.39 \pm 1.60 \mathrm{a}$ \\
\hline Cabbage $\times$ NS & $0.52 \pm 0.01$ & $0.23 \pm 0.01 \mathrm{ab}$ & $0.75 \pm 0.02 b$ & $219.5 \pm 4.70 \mathrm{e}$ & $49.51 \pm 0.40 \mathrm{~b}$ \\
\hline Rocket $\times$ C & $0.52 \pm 0.01$ & $0.21 \pm 0.01 \mathrm{bc}$ & $0.74 \pm 0.01 \mathrm{bc}$ & $390.6 \pm 7.31 \mathrm{a}$ & $31.78 \pm 0.53 \mathrm{~d}$ \\
\hline Rocket $\times$ NS & $\begin{array}{c}0.57 \pm 0.00 \\
\mathrm{~ns}\end{array}$ & $\underset{* *}{0.20 \pm 0}$ 土.01 c & $\underset{*}{0.77 \pm 0.01 \mathrm{~b}}$ & $246.3 \underset{* * *}{ \pm} 4.30 \mathrm{~d}$ & $\underset{*}{26.43} \pm 0.44 \mathrm{e}$ \\
\hline
\end{tabular}

ns, ${ }^{*}{ }^{* *},{ }^{* * *}$ denote non-significant or significant effects at $p \leq 0.05,0.01$ and 0.001 . Control: without nutrient supplementation; NS: with nutrient supplementation. All data are expressed as mean $\pm S E, n=3$. Different letters within each column(s) indicate significant differences compared by Duncan's multiple-range test $(p=0.05)$.

The human immune system is boosted by carotenoids (lutein, $\beta$-carotene), which possess a free-radical scavenging function, vanquishing cancer proliferation and shielding eye tissues [13]. Our observed trend regarding carotenoids response in rocket was in line with the results of Wieth et al. [25], but was the opposite for cabbage and Brussels sprouts; these species were in line with kale microgreens results presented by Kopsell et al. [42], where an increasing $\mathrm{N}$ rate provoked a linear increase of carotenoid pigments on a dry weight basis. Such findings corroborate the findings of Di Gioia et al. [3] that Brassica phytochemical biosynthesis and accumulation are primarily modulated by genetic factors. Interestingly, lutein and $\beta$-carotene showed a positive correlation with $\mathrm{K}$ concentration in these Brassica L. species, since K plays a main role in carotenoids' biosynthesis, affecting key enzymes like pyruvate kinase and phosphofructokinase [22]. As mentioned by Dhami and Cazzonelli [43], $\mathrm{N}$ addition increases the accumulation of $\beta$-carotene and lutein in various Brassica L. species. Neugart et al. [6] also confirmed that $\mathrm{N}$ supply is positively correlated with chlorophyll and carotenoid concentrations. $\mathrm{N}$ deficiency is expected to decrease the concentration of carotenoids because they make part of a photosystem downsized due to the lack of chlorophyll [22]. In contrast, Dhami and Cazzonelli [42] declared that nitrogen malnourishment increased $\beta$-carotene accumulation in microalgae, a finding that is in accordance with rocket behavior in this experiment, where nitrogen limitation reduced chlorophyll and increased photochemically inactive carotenoids [41]. Another putative mechanism could be explained by the high sensitivity of rocket to nitrogen, having an increase of ROS formation due to its mineral-deficient plant roots and causing an increase in carotenoids [22]. 


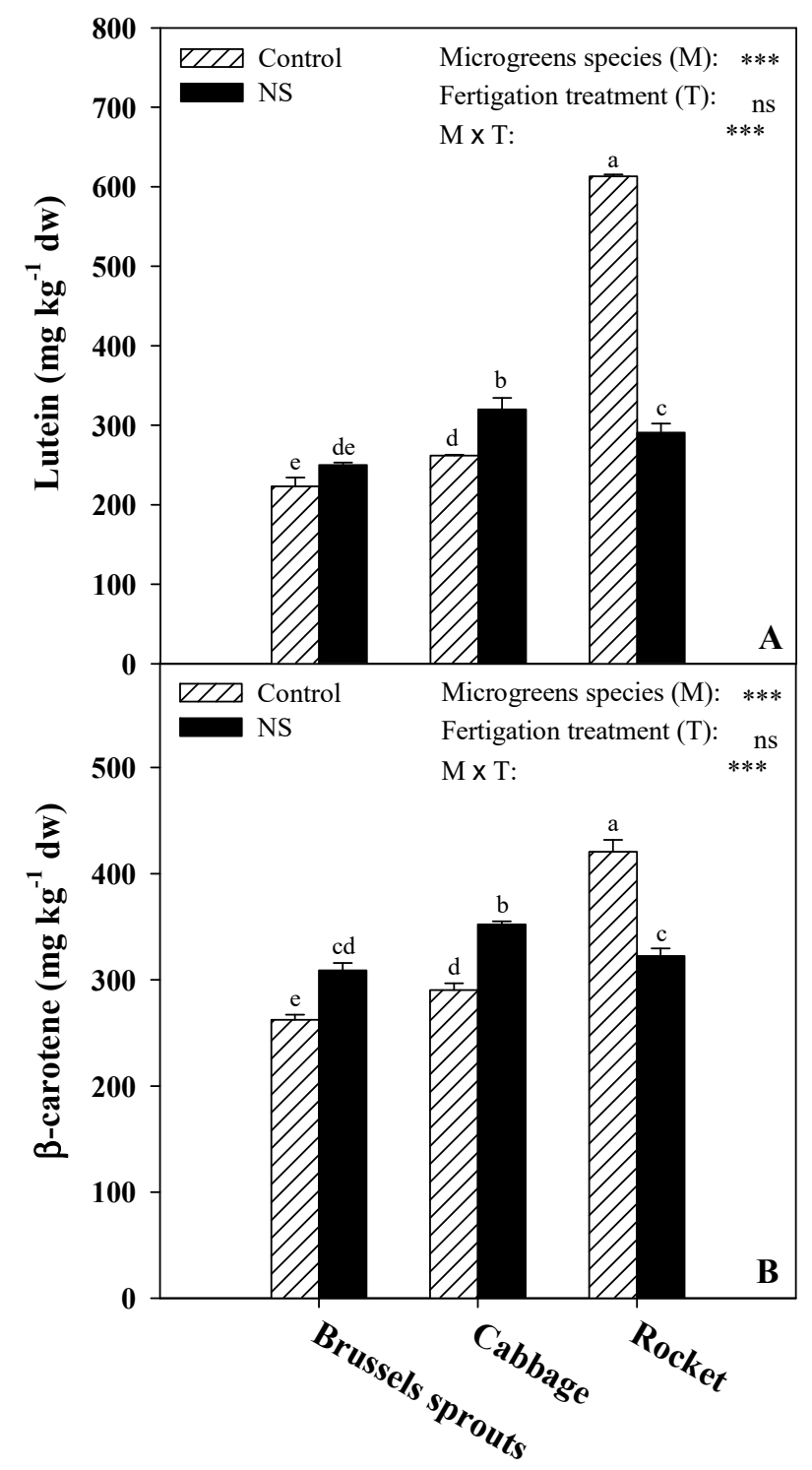

Figure 2. Lutein (A) and $\beta$-carotene (B) of microgreens species in light of the nutrient solution treatment. Control: without nutrient supplementation; NS: with nutrient supplementation. All data are expressed as mean $\pm \mathrm{SE}, \mathrm{n}=3$. ns, ${ }^{* * *}$ denote non-significant or significant effects at $p \leq 0.001$. Different letters (a-e; A and a-d; B) indicate significant differences compared by Duncan's multiple-range test $(p=0.05)$.

\subsection{Microgreens Total Ascorbic Acid Content and Total Anthocyanins}

Total ascorbic acid content in microgreens species (Table 3 ) was dictated by the interaction $\mathrm{M} \times \mathrm{T}$. It increased in cabbage and rocket by 1.3 and 1.6-fold, respectively, whereas it decreased by 1.2-fold in Brussels sprouts, when irrigated without nutrient supplementation. The highest TAA content was $390.6 \mathrm{mg} 100 \mathrm{~g}^{-1} \mathrm{fw}$, registered for rocket $\times \mathrm{C}$, while the

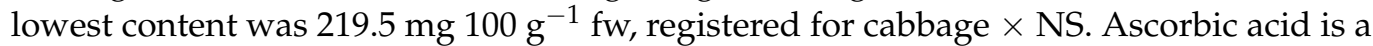
powerful water-soluble antioxidant [18]; it is a typical example of an imperative secondary metabolite that acts as enzymes 'cofactor, regulates the photosynthesis and cell division, other than being involved in the transduction of signals in plants [10], and inhibits the $\mathrm{N}$-nitroso compounds deriving from nitrite [44]. The TAA values obtained for Brussels sprouts were consistent with those obtained by Xiao et al. [45], where they were higher than those registered for cabbage. Moreover, the increase exhibited for TAA when no fertilization was applied is in line the results of Di Mola et al. [46] and Pannico et al. [47] obtained for mature and microgreens lettuce, respectively when no nitrogen was applied 
during the growing cycle. As explained by Mozafar [48], nitrogen boosts plant foliage growth, and therefore, less light is intercepted by the covered leaves inside the canopy and thus less ascorbic acid is accumulated in this shaded part. However, some species might respond differently to nitrogen deprivation, as in the case of Brussels sprouts in the current experiment. On the other hand, El-Nakhel et al. [22] attributed TAA accumulation to the activation of L-galactose dehydrogenase, which might be triggered by nutritional stress.

Similarly, total anthocyanin demonstrated a significant interaction between the two factors as listed in Table 3. A significant accumulation of total anthocyanin was obvious in both cabbage $(11.9 \%)$ and rocket $(20.2 \%)$, when irrigated without nutrient supplementation, whereas it maintained steady in Brussel sprouts at around $36 \mu \mathrm{g} \mathrm{g}^{-1} \mathrm{dw}$. In general, cabbage accumulated the most total anthocyanin $\left(52.45 \mu \mathrm{g} \mathrm{g}^{-1} \mathrm{dw}\right)$, followed by Brussels sprouts $\left(36.25 \mu \mathrm{g} \mathrm{g}^{-1} \mathrm{dw}\right)$ and then by rocket $\left(29.10 \mu \mathrm{g} \mathrm{g}^{-1} \mathrm{dw}\right)$.

Anthocyanins are strongly present in Brassica L. species, and they confer the purple color of some varieties, including the green cultivars [3]. These crucial secondary metabolites are highly hydro-soluble pigments that accumulate in cell vacuoles, in different concentrations and compositions depending on genetic and environmental factors, therefore giving diverse bright colors to the leaves [19]. Cabbage and rocket accumulation of anthocyanins proved to be consistent with the findings of Islam et al. [34], who demonstrated anthocyanin accumulation when red lettuce was under $\mathrm{P}$ deprivation. Indeed, $\mathrm{P}$ and $\mathrm{N}$ deficiency in red cabbage up-regulated the structural genes commanding anthocyanins' biosynthesis [3]. As stated by Neugart et al. [6], $\mathrm{N}$ supply is negatively correlated with flavonoid concentrations and positively correlated with carotenoids and chlorophylls.

\subsection{Microgreens Phenolic Acid Profile and Total Phenolic Acids}

Most of the phenolic acids listed in Table 4 showed no significant interaction between the two factors, except for Km 3-diglucoside, Qn 3-sophoroside-7-glucoside, rutin and synapoyl-hexose. The first three phenolic acids increased only in rocket, by 18.3, 28.4 and $18.4 \%$, respectively, when irrigated without nutrient supplementation, while the last phenolic acid decreased by $18.3 \%$. In addition, total phenolic acids in rocket decreased by $8.3 \%$ and registered $1198 \mu \mathrm{g} \mathrm{g}^{-1} \mathrm{dw}$ when it was irrigated without nutrient supplementation. Neither total phenolic acids nor single phenolic acids marked any changes when the fertigation switched from the modified Hoagland solution to water for both Brussels sprouts and cabbage microgreens. Overall, synapoyl-hexose was the most abundant phenolic acid in the three microgreens species, followed by trisinapoylgentionbiose, disinapoylgentiobiose and caffeoyl-quinic acid for both Brussels sprouts and cabbage, and by Qn 3-sinapoyltriglucoside, disinapoylgentiobiose and trisinapoylgentionbiose for rocket. 
Table 4. Phenolic acids and total phenolic acids ( $\left.\mu \mathrm{g} \mathrm{g}^{-1} \mathrm{dw}\right)$ of Brussels sprouts, cabbage and rocket microgreens in light of the nutrient solution treatment.

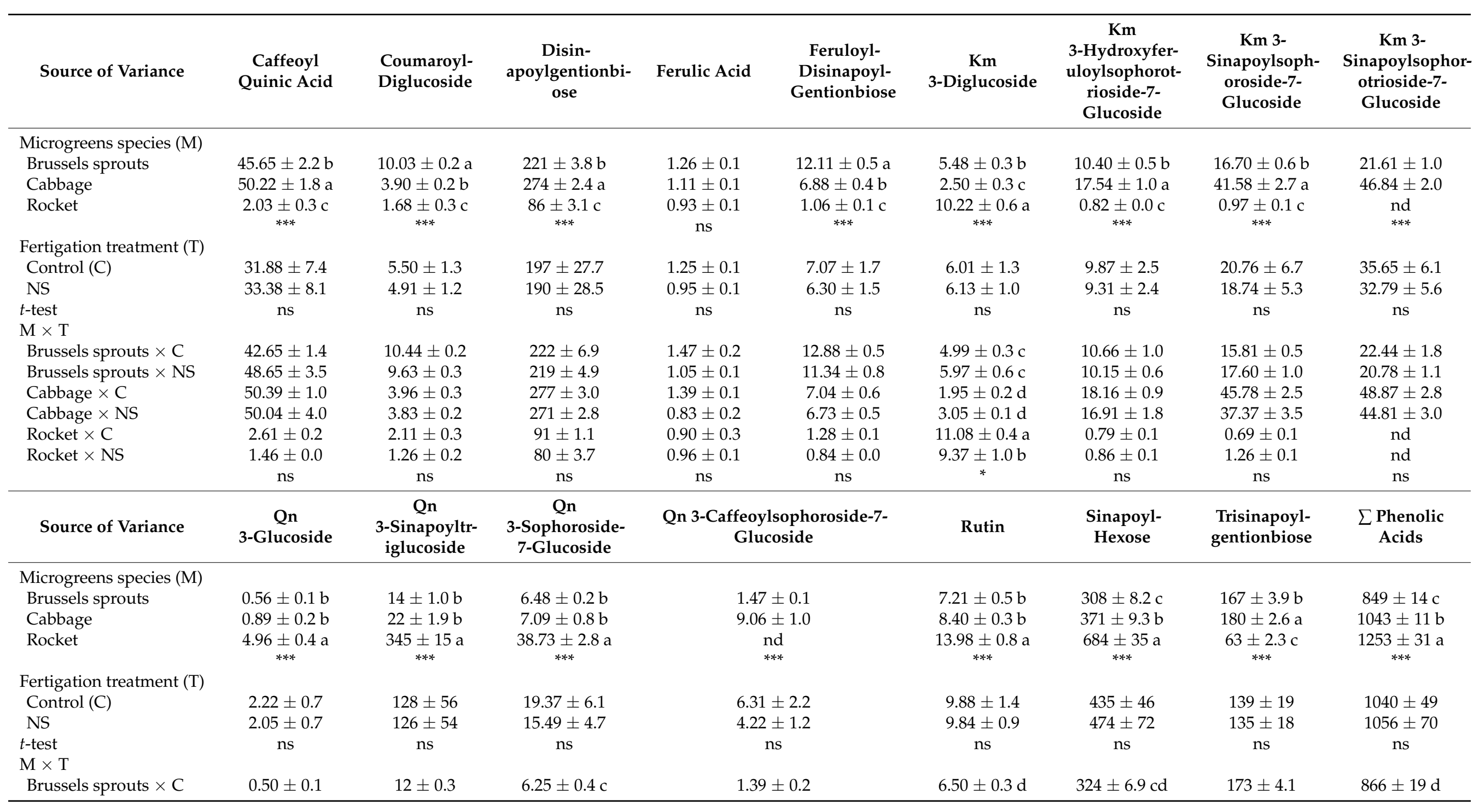


Table 4. Cont.

\begin{tabular}{|c|c|c|c|c|c|c|c|c|}
\hline Source of Variance & $\begin{array}{c}\text { Qn } \\
\text { 3-Glucoside }\end{array}$ & $\begin{array}{c}\text { Qn } \\
\text { 3-Sinapoyltr- } \\
\text { iglucoside }\end{array}$ & $\begin{array}{c}\text { Qn } \\
\text { 3-Sophoroside- } \\
\text { 7-Glucoside }\end{array}$ & $\begin{array}{l}\text { Qn 3-Caffeoylsophoroside-7- } \\
\text { Glucoside }\end{array}$ & Rutin & $\begin{array}{l}\text { Sinapoyl- } \\
\text { Hexose }\end{array}$ & $\begin{array}{l}\text { Trisinapoyl- } \\
\text { gentionbiose }\end{array}$ & $\begin{array}{l}\sum \text { Phenolic } \\
\text { Acids }\end{array}$ \\
\hline Brussels sprouts $\times$ NS & $0.62 \pm 0.1$ & $16 \pm 0.6$ & $6.70 \pm 0.2 c$ & $1.55 \pm 0.1$ & $7.92 \pm 0.7 \mathrm{~cd}$ & $293 \pm 7.8 d$ & $161 \pm 4.4$ & $831 \pm 19 \mathrm{~d}$ \\
\hline Cabbage $\times C$ & $1.21 \pm 0.1$ & $25 \pm 2.7$ & $8.32 \pm 1.2 \mathrm{c}$ & $11.23 \pm 0.6$ & $7.99 \pm 0.4 \mathrm{~cd}$ & $366 \pm 19 c$ & $181 \pm 4.8$ & $1056 \pm 18 \mathrm{c}$ \\
\hline Cabbage $\times$ NS & $0.57 \pm 0.1$ & $20 \pm 1.8$ & $5.86 \pm 0.2 c$ & $6.89 \pm 0.3$ & $8.81 \pm 0.4 c$ & $376 \pm 5.9 c$ & $179 \pm 3.3$ & $1031 \pm 13 c$ \\
\hline Rocket $\times$ C & $4.97 \pm 0.8$ & $348 \pm 30$ & $43.55 \pm 2.4 \mathrm{a}$ & nd & $15.16 \pm 0.5 \mathrm{a}$ & $615 \pm 10 \mathrm{~b}$ & $61 \pm 1.2$ & $1198 \pm 24 b$ \\
\hline Rocket $\times$ NS & $\begin{array}{c}4.94 \pm 0.5 \\
\text { ns }\end{array}$ & $\begin{array}{c}341 \pm 13 \\
\text { ns }\end{array}$ & $33.91 \pm 3.2 \mathrm{~b}$ & $\begin{array}{l}\text { nd } \\
\text { ns }\end{array}$ & $12.80 \pm 1.2 \mathrm{~b}$ & $753 \pm 37 a$ & $\begin{array}{l}65 \pm 4.7 \\
\text { ns }\end{array}$ & $1307 \pm 37 \mathrm{a}$ \\
\hline
\end{tabular}

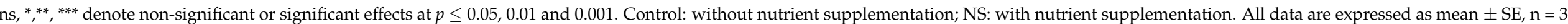
Different letters within each column(s) indicate significant differences compared by Duncan's multiple-range test ( $p=0.05)$. Km: Kaempferol; Qn: Quercetine. 
Plant species or genera are portrayed by signature plant secondary metabolites. Brassica L. species nutritional interest is somewhat pertinent to their rich phenolic compounds content, but the composition can be utterly diverse intra- and inter-species [8]. $\Sigma$ phenolic acids of cabbage were superior to those of Brussels sprouts, which is in line with the results of Xiao et al. [45], but rocket $\Sigma$ phenolic acids were the highest in our case, completely divergent from what the authors noted. Rocket phenolic acids modulation due to nutrient availability is partially in line with the statement of Neugart et al. [6], who indicated that kaempferol derivatives and quercetin glucosides of some Brassica L. species are negatively correlated with high $\mathrm{N}$ concentration. Conversely, Toscano et al. [33] stated that broccoli exposed to nitrogen stress exhibited a higher content of phenolic compounds. Amid plant stress, the production of secondary metabolites may be subjected to an increase due to an inhibition of growth and not photosynthesis, thus allowing the fixed carbon to be shifted to the secondary metabolites [49]. In our case, Brussels sprouts and cabbage microgreens were not influenced by the applied nutritional stress, which did not elicit any accumulation of phenolic acids. Rocket microgreens were severely affected by the nutritional stress in a scenario where both primary metabolism and phenolic acids were reduced, confirming that nutritional stress response is genotype-dependent [23].

\section{Conclusions}

Reshaping the nutritional architecture of plant foods is a valuable asset for the world's population, especially those who seek a healthy lifestyle based on a vegetable-rich diet. Restraining of the nutrient solution application during microgreens growth proved to be feasible for Brussels sprouts and cabbage, with minor yield reduction, exhibiting around $99 \%$ decrease of nitrate content and concomitantly maintaining steady colorimetric qualities and $\Sigma$ phenolic acids; only cabbage manifested a 30\% increase in total ascorbic acid and a $12 \%$ increase in $\Sigma$ anthocyanins. Although rocket manifested a major $47 \%$ decrease in yield, nutritional stress elicited an extensive increment in secondary metabolites like lutein $(110 \%)$, $\beta$-carotene (30\%), total ascorbic acid (58\%) and $\Sigma$ anthocyanins $(20 \%)$. Growing microgreens in a commercial peat-based substrate without fertilizer application can be feasible for certain species, such as Brussels sprouts and cabbage, thus lessening the economic cost and fertilization pollution and eliciting target secondary metabolites.

Author Contributions: Conceptualization, Y.R.; methodology, C.E.-N. and A.P.; software, C.E.-N. and A.P.; validation, C.E.-N., A.P., G.G., A.G. and M.C.K.; formal analysis, C.E.-N., A.P., G.G. and A.G.; investigation, C.E.-N., A.P., G.G. and A.G.; resources, Y.R.; data curation, C.E.-N. and A.P.; writing-original draft preparation, C.E.-N.; writing-review and editing, C.E.-N., M.C.K., A.R., S.D.P. and Y.R.; visualization, Y.R.; supervision, Y.R.; project administration, Y.R.; funding acquisition, Y.R. All authors have read and agreed to the published version of the manuscript.

Funding: This research received no external funding.

Data Availability Statement: The datasets generated for this study are available on request to the corresponding author.

Acknowledgments: The authors are grateful to Daniele Capurso, Luigi Formisano, Francesco Cristofano, Luigi Duri, Michele Ciriello and Maria Giordano for their technical assistance in the climate chamber experiment and the laboratory analysis.

Conflicts of Interest: The authors declare no conflict of interest.

\section{References}

1. Kyriacou, M.C.; Rouphael, Y.; Di Gioia, F.; Kyratzis, A.; Serio, F.; Renna, M.; De Pascale, S.; Santamaria, P. Micro-scale vegetable production and the rise of microgreens. Trends Food Sci. Technol. 2016, 57, 103-115. [CrossRef]

2. DellaPenna, D. Nutritional Genomics: Manipulating Plant Micronutrients to Improve Human Health. Science 1999, 285, 375-379. [CrossRef] [PubMed]

3. Di Gioia, F.; Tzortzakis, N.; Rouphael, Y.; Kyriacou, M.C.; Sampaio, S.L.; Ferreira, I.C.; Petropoulos, S.A. Grown to Be BlueAntioxidant Properties and Health Effects of Colored Vegetables. Part II: Leafy, Fruit, and Other Vegetables. Antioxidants 2020, 9, 97. [CrossRef] 
4. Lewis, W.H.; Elvin-Lewis, M.P.F. Medical Botany: Plants Affecting Human Health, 2nd ed.; John Wiley \& Sons: Hoboken, NJ, USA, 2003; ISBN 0471628824.

5. Raskin, I.; Ribnicky, D.M.; Komarnytsky, S.; Ilic, N.; Poulev, A.; Borisjuk, N.; Brinker, A.; Moreno, D.A.; Ripoll, C.; Yakoby, N.; et al. Plants and human health in the twenty-first century. Trends Biotechnol. 2002, 20, 522-531. [CrossRef]

6. Neugart, S.; Baldermann, S.; Hanschen, F.S.; Klopsch, R.; Wiesner-Reinhold, M.; Schreiner, M. The intrinsic quality of brassicaceous vegetables: How secondary plant metabolites are affected by genetic, environmental, and agronomic factors. Sci. Hortic. 2018, 233, 460-478. [CrossRef]

7. Herr, I.; Büchler, M.W. Dietary constituents of broccoli and other cruciferous vegetables: Implications for prevention and therapy of cancer. Cancer Treat. Rev. 2010, 36, 377-383. [CrossRef] [PubMed]

8. Cartea, M.E.; Francisco, M.; Soengas, P.; Velasco, P. Phenolic Compounds in Brassica Vegetables. Molecules 2010, 16, 251-280. [CrossRef]

9. Kapusta-Duch, J.; Kopec, A.; Piatkowska, E.; Borczak, B.; Leszczynska, T. The beneficial effects of Brassica vegetables on human health. Rocz. Państwowego Zakładu Hig. 2012, 63, 389-395.

10. Samuolienè, G.; Brazaitytè, A.; Viršilè, A.; Miliauskienè, J.; Vaštakaitė-Kairienè, V.; Duchovskis, P. Nutrient Levels in Brassicaceae Microgreens Increase Under Tailored Light-Emitting Diode Spectra. Front. Plant Sci. 2019, 10. [CrossRef] [PubMed]

11. Weber, C.F. Nutrient Content of Cabbage and Lettuce Microgreens Grown on Vermicompost and Hydroponic Growing Pads. J. Hortic. 2016, 3, 1-5. [CrossRef]

12. Kyriacou, M.C.; El-Nakhel, C.; Graziani, G.; Pannico, A.; Soteriou, G.A.; Giordano, M.; Ritieni, A.; De Pascale, S.; Rouphael, Y. Functional quality in novel food sources: Genotypic variation in the nutritive and phytochemical composition of thirteen microgreens species. Food Chem. 2019, 277, 107-118. [CrossRef]

13. Kamal, K.Y.; Khodaeiaminjan, M.; El-Tantawy, A.A.; Moneim, D.A.; Salam, A.A.; Ash-shormillesy, S.M.A.I.; Attia, A.; Ali, M.A.S.; Herranz, R.; El-Esawi, M.A.; et al. Evaluation of growth and nutritional value of Brassica microgreens grown under red, blue and green LEDs combinations. Physiol. Plant. 2020, 169, 625-638. [CrossRef]

14. Xiao, Z.; Lester, G.E.; Luo, Y.; Wang, Q. Assessment of vitamin and carotenoid concentrations of emerging food products: Edible microgreens. J. Agric. Food Chem. 2012, 60, 7644-7651. [CrossRef]

15. Mir, S.A.; Shah, M.A.; Mir, M.M. Microgreens: Production, shelf life, and bioactive components. Crit. Rev. Food Sci. Nutr. 2017, 57, 2730-2736. [CrossRef] [PubMed]

16. Caracciolo, F.; El-Nakhel, C.; Raimondo, M.; Kyriacou, M.C.; Cembalo, L.; De Pascale, S.; Rouphael, Y. Sensory Attributes and Consumer Acceptability of 12 Microgreens Species. Agronomy 2020, 10, 1043. [CrossRef]

17. Pannico, A.; El-Nakhel, C.; Graziani, G.; Kyriacou, M.C.; Giordano, M.; Soteriou, G.A.; Zarrelli, A.; Ritieni, A.; De Pascale, S.; Rouphael, Y. Selenium Biofortification Impacts the Nutritive Value, Polyphenolic Content, and Bioactive Constitution of Variable Microgreens Genotypes. Antioxidants 2020, 9, 272. [CrossRef]

18. El-Nakhel, C.; Pannico, A.; Graziani, G.; Kyriacou, M.C.; Giordano, M.; Ritieni, A.; De Pascale, S.; Rouphael, Y. Variation in Macronutrient Content, Phytochemical Constitution and In Vitro Antioxidant Capacity of Green and Red Butterhead Lettuce Dictated by Different Developmental Stages of Harvest Maturity. Antioxidants 2020, 9, 300. [CrossRef]

19. Oancea, S.; Oprean, L. Anthocyanins, From Biosynthesis In Plants To Human Health Benefits. Acta Univ. Cinbinesis, Ser. E Food Technol. 2011, 15, 3-16.

20. Rouphael, Y.; Kyriacou, M.C. Enhancing Quality of Fresh Vegetables Through Salinity Eustress and Biofortification Applications Facilitated by Soilless Cultivation. Front. Plant Sci. 2018, 9, 1254. [CrossRef] [PubMed]

21. Teklić, T.; Parađiković, N.; Špoljarević, M.; Zeljković, S.; Lončarić, Z.; Lisjak, M. Linking abiotic stress, plant metabolites, biostimulants and functional food. Ann. Appl. Biol. 2020, 12651. [CrossRef]

22. El-Nakhel, C.; Pannico, A.; Kyriacou, M.C.; Giordano, M.; De Pascale, S.; Rouphael, Y. Macronutrient deprivation eustress elicits differential secondary metabolites in red and green-pigmented butterhead lettuce grown in a closed soilless system. J. Sci. Food Agric. 2019, 99, 6962-6972. [CrossRef]

23. Senizza, B.; Zhang, L.; Miras-Moreno, B.; Righetti, L.; Zengin, G.; Ak, G.; Bruni, R.; Lucini, L.; Sifola, M.I.; El-Nakhel, C.; et al. The Strength of the Nutrient Solution Modulates the Functional Profile of Hydroponically Grown Lettuce in a Genotype-Dependent Manner. Foods 2020, 9, 1156. [CrossRef]

24. Murphy, C.; Pill, W. Cultural practices to speed the growth of microgreen arugula (roquette; Eruca vesicaria subsp. sativa ). J. Hortic. Sci. Biotechnol. 2010, 85, 171-176. [CrossRef]

25. Wieth, A.R.; Pinheiro, W.D.; Duarte, T.S. Purple cabbage microgreens grown in different substrates and nutritive solution concentrations | Microgreens de repolho roxo cultivado em diferentes substratos e concentrações de solução nutritiva. Rev. Caatinga 2019, 32, 976-985. [CrossRef]

26. Palmitessa, O.D.; Renna, M.; Crupi, P.; Lovece, A.; Corbo, F.; Santamaria, P. Yield and quality characteristics of brassica microgreens as affected by the NH4:NO3 molar ratio and strength of the nutrient solution. Foods 2020, 9, 677. [CrossRef] [PubMed]

27. Kyriacou, M.C.; El-Nakhel, C.; Pannico, A.; Graziani, G.; Soteriou, G.A.; Giordano, M.; Palladino, M.; Ritieni, A.; De Pascale, S.; Rouphael, Y. Phenolic Constitution, Phytochemical and Macronutrient Content in Three Species of Microgreens as Modulated by Natural Fiber and Synthetic Substrates. Antioxidants 2020, 9, 252. [CrossRef] 
28. Kampfenkel, K.; Vanmontagu, M.; Inze, D. Extraction and Determination of Ascorbate and Dehydroascorbate from Plant Tissue. Anal. Biochem. 1995, 225, 165-167. [CrossRef] [PubMed]

29. Lichtenthaler, H.K.; Wellburn, A.R. Determinations of total carotenoids and chlorophylls a and b of leaf extracts in different solvents. Biochem. Soc. Trans. 1983, 11, 591-592. [CrossRef]

30. Kim, H.-J.; Fonseca, J.M.; Choi, J.-H.; Kubota, C.; Kwon, D.Y. Salt in Irrigation Water Affects the Nutritional and Visual Properties of Romaine Lettuce (Lactuca sativa L.). J. Agric. Food Chem. 2008, 56, 3772-3776. [CrossRef]

31. Huang, H.; Jiang, X.; Xiao, Z.; Yu, L.; Pham, Q.; Sun, J.; Chen, P.; Yokoyama, W.; Yu, L.L.; Luo, Y.S.; et al. Red Cabbage Microgreens Lower Circulating Low-Density Lipoprotein (LDL), Liver Cholesterol, and Inflammatory Cytokines in Mice Fed a High-Fat Diet. J. Agric. Food Chem. 2016, 64, 9161-9171. [CrossRef]

32. Verma, N.; Shukla, S. Impact of various factors responsible for fluctuation in plant secondary metabolites. J. Appl. Res. Med. Aromat. Plants 2015, 2, 105-113. [CrossRef]

33. Toscano, S.; Trivellini, A.; Cocetta, G.; Bulgari, R.; Francini, A.; Romano, D.; Ferrante, A. Effect of Preharvest Abiotic Stresses on the Accumulation of Bioactive Compounds in Horticultural Produce. Front. Plant Sci. 2019, 10, 1212. [CrossRef] [PubMed]

34. Islam, M.; Lee, Y.-T.; Mele, M.; Choi, I.-L.; Kang, H.-M. The Effect of Phosphorus and Root Zone Temperature on Anthocyanin of Red Romaine Lettuce. Agronomy 2019, 9, 47. [CrossRef]

35. Pathare, P.B.; Opara, U.L.; Al-Said, F.A.J. Colour Measurement and Analysis in Fresh and Processed Foods: A Review. Food Bioprocess Technol. 2013, 6, 36-60. [CrossRef]

36. Di Mola, I.; Ottaiano, L.; Cozzolino, E.; Senatore, M.; Giordano, M.; El-Nakhel, C.; Sacco, A.; Rouphael, Y.; Colla, G.; Mori, M. Plant-based biostimulants influence the agronomical, physiological, and qualitative responses of baby rocket leaves under diverse nitrogen conditions. Plants 2019, 8, 522. [CrossRef]

37. Colla, G.; Kim, H.-J.; Kyriacou, M.C.; Rouphael, Y. Nitrate in fruits and vegetables. Sci. Hortic. 2018, 237, 221-238. [CrossRef]

38. Kyriacou, M.C.; Soteriou, G.A.; Colla, G.; Rouphael, Y. The occurrence of nitrate and nitrite in Mediterranean fresh salad vegetables and its modulation by preharvest practices and postharvest conditions. Food Chem. 2019, 285, 468-477. [CrossRef] [PubMed]

39. Waterland, N.L.; Moon, Y.; Tou, J.C.; Kim, M.J.; Pena-Yewtukhiw, E.M.; Park, S. Mineral content differs among microgreen, baby leaf, and adult stages in three cultivars of Kale. HortScience 2017, 52, 566-571. [CrossRef]

40. Kalaji, H.M.; Dąbrowski, P.; Cetner, M.D.; Samborska, I.A.; Łukasik, I.; Brestic, M.; Zivcak, M.; Tomasz, H.; Mojski, J.; Kociel, H.; et al. A comparison between different chlorophyll content meters under nutrient deficiency conditions. J. Plant Nutr. 2017, 40, 1024-1034. [CrossRef]

41. Berges, J.A.; Charlebois, D.O.; Mauzerall, D.C.; Falkowski, P.G. Differential effects of nitrogen limitation on photosynthetic efficiency of photosystems I and II in microalgae. Plant Physiol. 1996, 110, 689-696. [CrossRef]

42. Kopsell, D.A.; Kopsell, D.E.; Curran-Celentano, J. Carotenoid pigments in kale are influenced by nitrogen concentration and form. J. Sci. Food Agric. 2007, 87, 900-907. [CrossRef]

43. Dhami, N.; Cazzonelli, C.I. Environmental impacts on carotenoid metabolism in leaves. Plant Growth Regul. 2020, 92, 455-477. [CrossRef]

44. Mozafar, A. Decreasing the NO3 and increasing the vitamin C contents in spinach by a nitrogen deprivation method. Plant Foods Hum. Nutr. 1996, 49, 155-162. [CrossRef]

45. Xiao, Z.; Rausch, S.R.; Luo, Y.; Sun, J.; Yu, L.; Wang, Q.; Chen, P.; Yu, L.; Stommel, J.R. Microgreens of Brassicaceae: Genetic diversity of phytochemical concentrations and antioxidant capacity. LWT 2019, 101, 731-737. [CrossRef]

46. Di Mola, I.; Ottaiano, L.; Cozzolino, E.; Senatore, M.; Sacco, A.; El-Nakhel, C.; Rouphel, Y.; Mori, M. Trichoderma spp. and Mulching Films Differentially Boost Qualitative and Quantitative Aspects of Greenhouse Lettuce under Diverse N Conditions. Horticulturae 2020, 6, 55. [CrossRef]

47. Pannico, A.; Graziani, G.; El-Nakhel, C.; Giordano, M.; Ritieni, A.; Kyriacou, M.C.; Rouphael, Y. Nutritional stress suppresses nitrate content and positively impacts ascorbic acid concentration and phenolic acids profile of lettuce microgreens. Italus Hortus 2020, 27, 41-52. [CrossRef]

48. Mozafar, A. Nitrogen fertilizers and the amount of vitamins in plants: A review. J. Plant Nutr. 1993, 16, 2479-2506. [CrossRef]

49. Akula, R.; Ravishankar, G.A. Influence of abiotic stress signals on secondary metabolites in plants. Plant Signal. Behav. 2011, 6, 1720-1731. [CrossRef] 